continuing to increase their capacities by applying new technologies, and funding agencies supplying the necessary resources, sequencing the ocean or the contents of the human gut has become relatively easy. But how to extract meaningful information from a metagenome, and to gain insight into both the individual species' impact on the microbial community and the impact of this community on the ecosystem?

We can hope to unravel the function of every gene when individual species can be cultivated and genetically manipulated in the laboratory, but this is impossible when dealing with a complex community containing hundreds or thousands of species. Functional assignment of genes needs to be performed, even when the only information available is a string of nucleotide bases.

There are numerous databases and websites, public and not-sopublic, some adhering to an easily understandable framework of standards and regulation, and some not so transparent. Five years ago it was a big disappointment to compare one's chosen sequence with the GenBank database and not find a hit'. Today there is a feeling of sheer inadequacy in the face of vast quantities of sequence and annotation information - and an acute need for a degree in bioinformatics.

Publication in most cases (including the Nature journals) requires the deposition of sequence data into the GenBank or EMBL databases. Much less effort is spent depositing unpublished data or updating information that is already published. In all probability, in the not too distant future, metagenomic studies will be done not only by the big sequencing centres, but by anybody with a reasonable research budget and university support. To make all the data more easily accessible, it would be desirable to have a collaborative effort of genome centres and funding agencies to build a universal microbialsequence database, with a readily comprehensible framework for sequencing and annotation standards and regulations.

Microbiology has come a long way from investigating the easily cultured individual microbe from a rich microbial community and describing what is out there, and is now starting to get a grip on what they actually do. With the intrinsic difficulties of dealing with complex systems, it is good to see a field galvanized by new technologies and scientific daring. But more infrastructural order is required, to prevent the discipline getting ahead of itself.

\section{Success and successor}

\section{Exit an outstanding science minister; enter a more political operator.}

E arning the respect of the sector you represent isn't always a priority for a government minister, and can even lead your prime minister to suspect that you've 'gone native'. But when Tony Blair (to his credit) appointed David Sainsbury to be Britain's minister for science in 1998, he will have known that Sainsbury was native already, having a deep respect for science and having given it many millions of pounds of his personal philanthropy. Precisely because of his commitment to science, Sainsbury wanted that job and no other in government. That simple fact, combined with Sainsbury's quiet yet successfully determined support for science throughout his eight years, underlies the chorus of almost unmitigated praise from leading UK scientists following his resignation last week.

The disappointing aspects of this era mostly happened despite Sainsbury, rather than because of him. The 'spin' in government statistics - whether in budgetary announcements or in statistics of growth in undergraduate numbers - is a part of Blair's legacy for which his probable successor as prime minister, chancellor of the exchequer Gordon Brown, shares responsibility and would do well to discourage. As a government minister, Sainsbury cannot be wholly absolved from responsibility for something he nevertheless tried to resist: the relentless growth of academic bureaucracy, supposedly in aid of accountability. It no doubt runs counter not only to his sense of what researchers should be focusing on, but also to his experience, based in his family's supermarket empire, of how to run a business.

Sainsbury's strengths have included making the time to engage with scientists and to understand their goals. He has been influential internationally in his support for a politically untrammelled Euro- pean Research Council, and nationally in the way he has opposed and undermined vicious animal-rights activists. His time has been marred by accusations of conflicted interests, not least through hefty donations to a Labour party currently under police investigation for its handling of such support. But few believe that his reputation for integrity will be undermined when the results of that investigation are made public.

Sainsbury was luckier than most of his predecessors in that both his prime minister and his chancellor have been vigorous champions of science. But Sainsbury has had to defend his corner all the same. Now, the Treasury is focusing on critically analysing the benefits emerging from an unprecedented ten-year programme of annual increases in science funding.

Just what those increases amount to, given the exaggerations of spin and the pressures from commitments such as Iraq, education and public health, and just what benefits are demanded by the Treasury, are key issues for future scrutiny. Negotiating such challenges will be the responsibility of Sainsbury's successor, Malcolm Wicks - a member of parliament rather than a life peer and, by both definition and character, more of a political operator. Encouragingly, Wicks, in his current ministerial responsibilities for energy (which he will leave behind), has shown himself to be a good listener, prepared to consider evidence, and prepared to engage with lobbyists - yet also to face them down in public.

The respect and experience that Sainsbury has gained will stand him in good stead as he tackles his next commitment for the government: developing a strategic review of UK science policy. In this role, and in his position in the House of Lords, where he can scrutinize government legislation, and as a philanthropist, he can still influence science, and has earned the right to do so. 